\title{
Blasts More than 25 Percent of Bone Marrow Nucleated Cells
}

National Cancer Institute

\section{Source}

National Cancer Institute. Blasts More than 25 Percent of Bone Marrow Nucleated Cells. NCl Thesaurus. Code C148287.

A semi-quantitative microscopic finding indicating that more than 25 percent of the nucleated cells in a bone marrow sample are immature mononuclear cells. 